\title{
IS GOLD JEWELRY MONEY?
}

Peter Oakley

\begin{abstract}
This article explores the extent to which gold jewelry, an object type conventionally looked on as a means of display, should also be seen as a type of money. Drawing on historical evidence and ethnographic research, the analysis considers the ways in which two examples-the Renaissance money chain and the modern jewelry collection-exhibit characteristics fundamental to money: liquidity, partibility, and recursive divisibility. As a result, this study proposes that gold jewelry can best be described as a type of para-money. The article concludes that due to its ambiguous state, gold jewelry is able to act as a mediator in social situations where exchanges of money proper are considered unacceptable, and that this is an important yet underacknowledged aspect of its social identity.
\end{abstract}

Keywords: gold, hallmarking, jewelry, money chains, recursive divisibility, specie

Saving your merry humour, here's the note.

How much your chain weighs to the utmost carat.

- The Comedy of Errors, Act IV, Scene 1

In November 2010, Robert Zoellick, the president of the World Bank, made a speech that caught economic journalists' attention. He proposed that policy makers should start to consider employing gold as "an international reference point” (Harding et al. 2010). At face value, Zoellick's comment was unsurprising. Policy makers needed to gauge consumer sentiment, and stating that the price of gold accurately reflected investor anxiety was not controversial. But having supported the 100-year-long project to try to wean the world off gold as money, the world's central bankers were less than enthusiastic to give the yellow metal a new role in international finance.

At the time Zoellick made this statement I was undertaking fieldwork on the fine jewelry industry and gold supply chains. The minor furor and 
misinterpretations that followed his speech reinforced my observations that gold could inspire acute anxiety among bankers and traders. Fieldwork also offered numerous other insights into the uncomfortable relationship between gold and most of the world's fiat currencies. Gold's apparently unstoppable rise in value and respect had had dire consequences for the jewelry industry during my time in the field. In the course of the five years that I observed the sector, entire sections of the fine jewelry trade and precious metal refining industry were reconstructed by a rapidly changing social landscape.

Gold's capacity to undermine, as well as underpin, economic systems and even its own supply chains is not a recent development. The adoption of legally protected gold coinage, or specie, across medieval Europe brought with it intractable social problems particular to its materiality (see Bordo and Schwartz 1996; N. Clark 2014; Eichengreen and Flandreau 1985; Oakley 2013; Porteous 1973). These persisted until specie's fall from grace in the early twentieth century. Equally, in the contemporary world, gold continues to defy its reclassification as a classical commodity (Bernstein 2004; Blas and Mackintosh 2009; Green 1982; Hart 2013).

\section{The Consequences of Material Money}

In the introduction to this special issue, Sandy Ross, Mario Schmidt, and Ville Koskinen note that despite their diverse material forms, different types of money are overwhelmingly treated as conceptually similar, somehow sharing an innate abstractive quality that negates material specificity. While acknowledging concerns that a focus on material qualities has too frequently led to unhelpful overemphasis on the immediate phenomenological properties of tokens of exchange (Holbraad 2005), the wider consequences of materiality still need to be considered in more depth. My continued adherence to this approach is due to the importance of material networks that make money exist as money. James Buchan (1997: 7) poetically reflects on using a Saudi Arabian riyal note to pay a Lebanese waiter: "The banknote was an outcrop of some vast mountain of social arrangements." Money exists as money only if it is facilitating these types of arrangements. Money as a total abstraction cannot actually be studied at all—only speculated on (Yuran 2014; Zelizer 1997).

Why is dwelling on this important? The material chosen to make money a concrete entity can have much wider social resonances. Although in the case of fiat currencies the leakage between the two identities is so limited as to be negligible-we do not see paper money and other pieces of paper as readily interchangeable-in the case of other types of money, particularly money made from precious metals, this incommensurability is less evident. This difference undermines the notion that we can simply extrapolate the experience of using a fiat currency to encompass all monetary relations.

The credit and sovereign debt crises of the past six years have exposed the specific mechanisms needed to maintain a fiat currency to an unprecedented degree, while emboldening the critics of these types of currency systems (e.g., 
Eisen 2012; Harding et al. 2010; Mattingly and Schmidt 2010). In the United States, a vocal section of the political right has consistently advocated a return to a precious metal based coinage, which it claims would inevitably engender a return to fiscal prudence (Lewis 2007). Yet the alternative monetary tokens created to facilitate this shift, such as silver 'liberty' dollars, have repeatedly fallen prey to compromising scams. These events expose the astounding naiveté on the part of actors regarding how currency systems rely for their continued existence on governmental power, rather than common goodwill or the invisible hand' of the free market.

The fundamental risk faced by monetary economies based on precious metal coinage has always been the material coin itself. Problems that can arise include a crisis of trust in authenticity or face value, the overall supply, or a sudden decline in the velocity of circulation. Sometimes these factors combine, with each reinforcing the effects of the others. Regional or even national financial breakdowns caused by a lack of specie in circulation were once endemic (Clay and Tungate 2009; Eichengreen and Flandreau 1985; Levenson 2009). Social disruptions from war to crop failure could lead to a 'run on the banks', when a large percentage of the population would fight-sometimes literallyto convert wealth from paper derivatives, such as promissory notes, into gold coins, which were then hoarded (Bernstein 2004). Economic collapse could also be precipitated by a sequence of events unimaginable in a fiat system. In 1857, the steamer SS Central America was lost in a hurricane in the Gulf of Mexico. As the ship was carrying stocks of gold to replenish the coinage desperately needed by US East Coast cities, news of the disaster led to financial panic (Kinder 1998; Klare 1991).

Although more restricted than a medium of exchange that relies on immediate claims of value, such as salt (Godelier 1971) or grain (Fuller 1989), specie is more intrinsically international than a fiat currency. The gold content in the specie of one nation or empire enables it to operate as a para-currency in all others that adhere to a gold standard. Specie's material basis also offers potentials not available to fiat currencies. In a fiat system, the lowest denomination coin is the practical limit case of divisibility for direct exchange, and the value of every token is immutable. Stock market trades may be conducted at small fractions of the smallest unit of the currency, but these can only be redeemed once aggregated to a workable level. In contrast, each individual piece of specie holds the potential of apparent boundless divisibility. In practice, gold coins could be, and often were, cut in half or further subdivided and then used for trade (Porteous 1973). While these divided coins were no longer sanctioned currency, at times they took on an important role in the money supply.

The material nature of specie resulted in specific day-to-day anxieties and behaviors. Trading was accompanied by continual checking to ensure that each gold coin being proffered was not a forgery and contained sufficient gold. Delicate miniature beam or cantilever balances made specifically to test specie were an essential possession of every banker and trader. Reconfirming the material validity of tokens of exchange became a ritual element of trading, defining not only the speed of trade and the behavior of participants, but also 
their expectations of how trade should be conducted as a performative act. Today, the process of weighing coins has been 'black boxed' by technologies to the extent that we barely perceive it unless a machine summarily rejects our money. Our confusion in such situations-is this a fault in the machine or is the coin somehow sub-standard or fake?-illustrates how little we are aware of what the coins we use should feel like. In a specie-based economy, the immediate physical qualities of precious metals cannot be partitioned off from the way the entire economic system is structured and functions. To take Marshall McLuhan's ([1964] 2001) axiom in a new direction, in the case of specie, the medium really is the message.

\section{Defining Jewelry}

While specie is overwhelmingly considered to be a functional financial instrument, jewelry is typically framed as a personal valuable primarily intended for social display. This position informs popular notions as well as anthropological and sociological academic discourse (Bourdieu [1984] 2008; Goffman 1951; Simmel 1997; Weiner 1992). In practice, the multivalent identity of gold jewelry enables it to undertake other types of social work, although these are usually elided or left purposefully indistinct. To uncover them, we will start with an examination of what the word 'jewelry' actually refers to in practice, and then move on to consider a historic type of jewelry that challenges common-sense descriptions. We will conclude with an analysis of recent events which show that even contemporary gold jewelry is treated by individuals as an object type much closer to money than is generally acknowledged.

In academic contexts, the terms 'jewelry' and 'personal adornment' are often used interchangeably, which poses problems for historians of art and design and anthropologists alike when they attempt to categorize things that people drape, tie, bind, or push through parts of their body, either using pre-existing protrusions, cavities, or holes, or making new ones expressly for the purpose. Yet the general understanding of the English word 'jewelry' is much more restricted in daily use. Most Westerners accept that others may use dog's teeth, feathers, or nuts for adornment and will admire the results when these are exhibited within the confines of ethnographic collections. But they have no intention of wearing such things themselves. The range of materials that can be used to make high-status jewelry is actually very narrow, highly stable, and easily identifiable: gold, platinum, silver, and the 'big five' gems (diamonds, rubies, sapphires, emeralds, and pearls). This convention has a very long history in Europe and elsewhere (G. Clark 1986; Cocks 1980; Forsyth 2013).

Three descriptive labels widely used in the jewelry trade-fine jewelry, costume jewelry, and fashion jewelry (Event Guides 2011; Goldsmiths 2011; Reed Exhibitions 2011)-illustrate this neatly. Fine jewelry is made from the historically sanctioned expensive materials. Costume jewelry formally copies fine jewelry but falls short in terms of its materials. Fashion jewelry is formally eclectic, low value, and disposable. It is as impossible to make fashion jewelry 
from gold and diamonds as it is to make fine jewelry from plastic and hemp. Gold jewelry is understood to be fine jewelry, and the higher the gold content of the gold alloy, the better. Although artisanship has some role in appraisal, the materials still make the object what it is. This is a strange situation. Object categories are not generally materially constrained. For example, a chair is still a chair, whether it is made of wood, metal, or glass. ${ }^{1}$

\section{Money Chains}

Although these two classes of objects-specie and jewelry-are generally considered to have very different social roles, there is evidence that conceptual confluence exists in practice. This can best be illustrated by examining the social identity of a specific type of jewelry that was popular for more than 100 years: the money chain. Wearing elaborate gold collars or chains made of decorated links was a common practice among European nobility and senior officials in the late Middle Ages and the Renaissance. Effigies on the tomb of Philip the Handsome and Juana la Loca, carved in 1519 and 1520, represent them both wearing such collars (Muller 1972). Extant paintings show, and contemporary documents describe, the familial or personal emblems represented on each link. These designs also featured on the chains-of-office of senior retainers. John of Gaunt (1340-1399), his son Henry IV of England, and his nephew Richard II of England all used the double-S symbol, which was revived by the founder of the Tudor dynasty, Henry VII (1457-1509) and eventually became the badge of office of the entire English royal household (Evans [1953] 1970).

By the sixteenth century, a fashion had developed for also wearing heavier chains with simple ' $O$ ' shaped links. Portraits from the early and mid-1500s provide ample evidence of this practice. Examples from the northern states of Europe include Strigel's portrait of Hieronymus Haller (1503) and the infamous Holbein portrait of Anne of Cleeves (1539). That Anne chose to be depicted wearing such chains for a portrait intended to enchant a future royal husband indicates the allure of these objects to contemporary viewers of the painting.

Simple gold chains were also adopted as personal adornment lower down the social scale. Rich German townswomen increasingly displayed their wealth by the number of simple gold chains they wore (Lightbrown 1992). That gold jewelry had become popular elsewhere among the general populace is evidenced by an exchange between the Silesian knight Nicholas von Popilievo and an inhabitant of Seville. Outraged at being asked if he is a knight, Von Popilievo replies: "Can you not see the ensigns of a knight hung around my neck? Know that in my country it is not a custom for pagans, Jews and rustics to adorn themselves with gold as they do in yours: Only knights may do this" (quoted in ibid.: 241). Von Popilievo's outburst indicates the extent to which Spain's recent conquests in the New World, and the resulting influx of gold, had led to innovations in adornment.

In 1980, the remains of the Spanish treasure ship Santa Margarita were discovered off the Florida Keys. The Santa Margarita sank in a hurricane in 1622, a 
century after simple gold chains had become popular in Europe, but finds from the wreck proved that they were still fashionable. The recovery of more than 50 money chains confirmed a consistent feature of these objects that had been suspected from previous examinations of the few remaining scattered examples: each link in a money chain weighed exactly an ounce (Shaughnessy 2004). This regularity was no coincidence. The gold links weighed the same as a contemporary Spanish eight escudo gold coin. If pressed for cash, a wearer could simply remove a link from the chain and use it as payment. The malleability of high-carat gold alloys made this action possible without recourse to specialist equipment. A money chain therefore came as close to being interchangeable with contemporary currency as it was possible for a non-specie object to be.

The ostentation of the money chain interacted with the practicality of its use as a means of payment. The simplicity of each of the links was more than just an aesthetic choice; their form made it relatively easy to determine the weight and specific gravity of the link. As these were needed to complete a comprehensive gold assay, the form of the money chain facilitated its functionality as an object of exchange. In the money chain we find a piece of jewelry that exhibits the same properties as money in terms of recursive divisibility. The chain is a conceptual whole made up of many subsidiary but equally recognizable and potentially independent wholes. It is also partible: once a link is removed, the owner retains the original chain and 'gains' an additional object, the single link. The extent to which a money chain can repeatedly relinquish links and still retain conceptually integrity does have a limit, much like the sorites paradox. ${ }^{2}$ But it is worth noting that money chains were far longer than the gold chains that are worn today. One of the money chains found in the wreck of the Santa Maria was over three meters in length.

The simplicity of the money chain had another aspect-formal anonymity-that also supported its use as an object of exchange. Whereas the heraldic imagery of emblematic collars restricted their circulation to related individuals and their servants, a simple gold chain could be worn by anyone. Thus, a money chain could potentially circulate with spectacular velocity, taking one of many alternative possible pathways. As well as gifts of esteem or parts of dowries, money chains were used as bribes or rewards for political services rendered. Henry VIII of England was not above requisitioning a chain from one courtier to give to another as a reward for a favor (Lightbrown 1992). Their obvious value and anonymity led to a role in international relations. The convention arose of giving foreign ambassadors a plain gold chain as a parting present. When the Republic of Venice decided that returning ambassadors had to surrender these gifts to the city-state's treasury, it led to passionate, although unsuccessful, petitions from the Republic's aggrieved statesmen.

The money chain's ability to announce wealth but not origins was not lost on contemporary social commentators. Shakespeare makes use of the money chain's obvious value and subtle ambiguities in The Comedy of Errors, first performed in 1604. The action takes place in Ephesus, a town where trade and profit are paramount and personal relationships are frequently compromised by the urge for material gain. The plot, which hinges on mounting confusion 
surrounding the identities of two pairs of identical twins, relies in part on a sequence of misunderstandings over a substantial gold chain. The action and moral message of Shakespeare's dark comedy relies on the multiplicity of social pathways open to such an object. Originally intended as a gift for a wife, the gold chain is mistakenly given to and worn by one of the twins, then coveted by a courtesan. The chain's lack of any secure position or clear identity mirrors that of the play's main protagonists. It is worth noting that in order for events of the play to be understood, the ambiguity of the gold chain had to be obvious to contemporary audiences. The Comedy of Errors illustrates not only that the money chain as object type mediated a diverse range of relationships and interactions in Renaissance Europe, but also that the money chain's social liquidity led to a measure of disquiet and critical comment.

Should we see the money chain as simply a type of money? I would contend it is more interesting than that. Money chains were socially ambiguous and thus a suitable means of rewarding individuals in situations where an overt payment made using something accepted as money would be considered either crass or socially reprehensible. It is the very ambiguity of the money chain as an object-directly comparable with money, but not quite money-that made it a suitable political gift, component of a dowry, or present to a courtesan. Its precise value could be both closely calculated and ostensibly ignored.

\section{Researching Jewelry in a Time of Economic Crisis}

Are money chains a historic anomaly? Or are they a type of gold jewelry that makes an inherent aspect of jewelry become more obvious? The money chain as an object form has no direct correlation with the predominant types of jewelry offered for sale today by most high street jewelers in Britain. The closest object is the rapper chain, worn by some hip hop music enthusiasts. But these objects are usually made from gold alloys with a far lower gold content, making them ersatz copies rather than modern equivalents of the money chain. Most other typical forms of jewelry are far more delicate in construction and lighter in weight, with design and artisanship rather than weight as the overriding factor in their appeal and an apparently significant factor in their initial retail price. However, these differences mask an underlying similarity that becomes apparent only at specific moments in each piece of jewelry's later social trajectory.

Observing these moments is not easy, although during my fieldwork in the jewelry industry, exceptional circumstances made them more frequent and numerous. The year 2008 saw the start of a long-running economic crisis that led to a flight to safe financial instruments, and, as a consequence, the gold price rose continuously for more than four years (CPM Group 2014; O'Connell et al. 2013). Although the 2008-2012 climb in the gold price was unprecedented, fieldwork interviews with industry professionals revealed that this instability was a chronic rather than acute feature of the jewelry industry. Respondents described previous sudden climbs and crashes in the gold price. These included a major spike in the early 1980s that resulted in a 'gold rush' in London's 
jewelry district, with queues of people stretching down the street waiting to sell their gold jewelry at the refiners' commercial trade counters.

In contrast, the length and consistency of the rise in the gold price between 2008 and 2012 presented an opportunity for alternative 'scrap gold' purchasers to set up businesses in competition with established pawnbrokers and industrial trade counters. The industry also witnessed the arrival of postal gold companies that bought gold items sent through the mail. During 2010, magazines and UK daytime television were saturated with advertisements encouraging the public to sell unwanted gold jewelry (English 2012; Saner 2012). These purchasers became known collectively as 'cash-for-gold' businesses. In 2013, stagnating gold prices, the decline in sources of easily available scrap, and increasing concerns about the low prices being paid by many cash-for-gold companies caused the collapse of the cash-for-gold market. By 2015, the number of scrap purchasers had returned to something approaching the same size as before the boom.

My participant-observation activities as an assayer and refinery worker revealed the hidden side of these cash-for-gold operations: staggering amounts of gold jewelry that was purchased and processed as scrap. Thousands of kilos of jewelry were melted down to make gold 'melt bars' that were sold to the large refiners to be turned into gold bullion, which was then sold on the international exchanges (see CPM Group 2014; O'Connell et al. 2013). At field sites, any interest in the composition of the trays full of jewelry, called musters, waiting to be melted down was not encouraged, and I was repeatedly warned not to inspect these tangled piles of jewelry. The convention was to treat the musters as undifferentiated raw material rather than a collection of discrete objects. From conversations with refinery staff, I discovered that this overt denial of the 'objectness' of the jewelry in front of them was learned behavior. When asked if he ever thought about the jewelry he destroyed each day, one respondent told me: "Well, I did at first, but now it all just sort of passes in front of me. It's a bit depressing to even go there."

Musters were predominantly composed of two types of jewelry. The first was small nondescript items: thin chains, earrings, and pendants that could have been made any time over the past half-century. The second was larger and heavier unfashionable objects that could be fairly closely dated on stylistic grounds. Examples were 'gypsy bangles', Dunhill lighters, charm bracelets, and ingot pendants, all of which were popular in the 1970s and early 1980s. When tactfully prompted, it turned out that furnace operators were fully aware of the nature of the jewelry they were destroying. They could even describe trends in the appearance and disappearance of different types of items. One worker explained that gypsy bangles, which had been extremely popular in the 1970s and 1980s, were now too dated to be resold by jewelers or pawnbrokers as jewelry but fetched a good price when sold as scrap due to their relatively high weight. The same applied to gold Dunhill lighters, which had become less resalable because of long-term decline in smoking and associated public rituals, such as lighting someone else's cigarette. Referring to the extremely nondescript items, one furnace operator remarked that he was "gradually destroying all the crap Ratner had made a fortune selling in the 80s." This was an astute 
reference to Gerald Ratner's well-known chain of jewelry stores that had sold huge volumes of cut-price 9 carat jewelry during the 1980s. The company had almost gone bankrupt in 1991 after Ratner made an ill-advised speech at a Confederation of British Industry (CBI) dinner, boasting that his products were poorly made rubbish (IOD 2013; Ratner 2007).

The pieces of gold jewelry that predominated in the musters were middling in both value and aesthetics. While holding enough value as stores of gold to be worth the effort of taking them to be scrapped, they were not valuable enough or aesthetically significant enough to be cherished as status symbols. It was this combination of material and formal mediocrity, together with the underlying value of their material composition, which led to their eventual assimilation into the muster. In contrast to the recursive divisibility of the money chain, the muster was conventionally treated by handlers as an indivisible conceptual entity, despite their knowledge that it consisted of a multiplicity of individual objects. This conceptualization, demanded by the context of its assembly as a muster, foreshadowed the physical unification of the gold jewelry into the form of the melt bar. However, this was not the case for other, far longer-lived private assemblages: jewelry collections.

\section{The Jewelry Collection as a Meta-Object}

It was fieldwork among retail sales staff that provided crucial insights into the nature of the jewelry collection as a meta-object, as well as the earlier trajectories of objects that constituted the major part of refinery musters. As a result of their work with extraordinary pieces, art and design historians, museum curators, conservators, and action house appraisers all display a marked tendency to consider gold jewelry as singularities and to emphasize rare or unique features (e.g., Bury 1984; G. Clark 1986; Dormer and Turner 1985; Orrling 2002). In fairness, the individuality of the items they deal with strongly supports this approach. But this perception of jewelry contrasts with that of shop assistants on high streets in Britain. They, and many of their clients, considered jewelry in more relative terms. These consumers owned a jewelry collection that existed as a fluid meta-object containing a number of visually and materially related items.

Jewelry collections were usually the outcome of a sequence of purchases that had taken place over years. In jewelry stores, consumers would deliberate over new purchases, reflecting on whether a potential addition would 'go with' (i.e., neither aesthetically clash nor formally duplicate) the pieces they already owned. As different colored metals do not visually complement each other, gold owners were future gold buyers. Once established as collections, these assemblages held the capacity to expand indefinitely, being limited only by the availability of suitable items and the financial resources of the owner. A jewelry collection could also contract or change some of its individual constituent pieces at any point without suffering conceptual dissolution. Jewelry that became unfashionable was increasingly at risk of being 'dropped', a decision that would lead to its appearance in a muster at a future point. The owners of 
jewelry collections almost invariably possessed individual items of high symbolic or sentimental value, such as engagement or wedding rings. These would be understood to be on a different register and were treated as distinct from the collection, although they usually aligned with it to some degree in terms of visual aesthetics and material composition.

A jewelry collection as a whole reflects the changing financial status and personal taste of the owner. Its fluidity is critical to its longevity as a meta-object. While similar inward flows are common to all collections of objects, controlled outflows are generally much more problematic to maintain. In the case of gold jewelry, this was achieved in large measure by a unique feature of jewelry made using precious metals: the hallmark. In Britain, it is a legal requirement that any object offered for sale that is claimed to be made of gold-with the exception of extremely small items or medical or scientific equipment-must have a hallmark that has been applied at one of the four registered Assay Offices. A hallmark identifies the percentage of gold in the alloy the item is made of, as well as where it was marked and who submitted the item for marking. As Britain is a signatory to the international treaty known as the Precious Metals Convention, gold objects bearing similar assay marks from other signatory countries are also legally acceptable in Britain. ${ }^{3}$ The existence and ubiquity of the hallmark means that anyone handling a piece of hallmarked jewelry can quickly and reliably calculate the amount of gold that it contains.

This hallmarking system allowed cash-for-gold businesses to give immediate scrap valuations for gold objects presented to them and allowed owners to calculate how close the offer was to the day's spot price for gold. Hallmarks are also a guarantee against fraud, due to the Assay Offices' expertise, the government's protective legislation, and active policing policies. Consequently, the hallmarking system facilitates both the commodification and destruction of gold jewelry. By offering a guarantee of the gold content, it increases the liquidity of gold jewelry in general and the fluidity of every jewelry collection in the United Kingdom.

The jewelry collection as a meta-object exhibits the same recursive divisibility as the money chain or the heap of gold coins. In contrast to the coins, whose liquidity was determined by their status as a legal, material token of exchange, and the money chain, whose liquidity was facilitated by the form of its constituent links, the liquidity of the jewelry collection is facilitated by the existence of the hallmarking system. This permits individual pieces of gold jewelry items to be highly variable in terms of form, weight, and composition because a scrap buyer can still easily and confidently determine the overall gold content by weighing the item and making a simple calculation using the information embedded in the hallmark.

\section{Jewelry as Money?}

This leads us to some final key questions. Martin Holbraad (2005) argues that money is uniquely divisible, with an exceptional capacity for displacement. But we have seen in the examples above that particular types of gold jewelry, and 
some aggregations of gold jewelry, exhibit the same properties. There are two possible conclusions to consider. Either money is less exceptional than claimed, or gold jewelry is actually a type of money, although not recognized as such. I should add a couple of caveats here, as they will help us take the last steps. Not all gold jewelry carries the same capacity for circulation. We have already noted that some object forms, including the heraldic collar, engagement ring, and wedding ring, are just too individual to circulate with any great velocity (English 2012; Saner 2012). We could list other, similarly exceptional items, such as royal regalia, Fabergé eggs, and Bronze Age torcs. The key word here is exceptional: the more mediocre or unremarkable an object becomes, the more likely it is to circulate unimpeded, with its material content determining the upper limit of its value.

So how much anonymous jewelry actually exists? As I mentioned earlier, the amounts only start to become apparent when one sees the musters of gold on the refiner's shop floor. The exceptional pieces of gold jewelry, from crowns to torcs, really are the exception in terms of overall weight of gold being used. In 2009, the UK's jewelry industry used 325,000 troy ounces (just over 10 metric tons) of gold to make jewelry, according to market analysts CPM Group (2014). This was also the first year in over a decade that more gold jewelry was scrapped in the United Kingdom than fabricated (Flood 2010). But as previously noted, this figure was a low point for industrial gold jewelry fabrication. In 2001, the UK jewelry industry needed 1,185,000 troy ounces of gold, almost 37 metric tons. In the same year, overall commercial jewelry manufacture across Europe accounted for 23,375,000 troy ounces, just more than 737 metric tons (CPM Group 2014), while the Italian gold jewelry industry alone, which specializes in mass producing standard chains (Green 1968), used 16,900,000 troy ounces, more than 525 metric tons (CPM Group 2014). Despite these large figures, we must acknowledge that the aggregated objects discussed here are far more limited than most types of money. As a microcosm, a single link is a far larger element of the macrocosm of the money chain than a single currency token is of an entire currency. In addition, it was the link's direct comparability to the contemporary units of currency in terms of overall weight and material composition that enabled the owner to make an accurate evaluation of its value. Taking this into account, the money chain should be considered a type of para-money rather than money proper.

Equally, when considering the value of the masses of unremarkable jewelry that constitute most jewelry collections in the United Kingdom, one has to recognize how much smaller the overall amounts are in relation to the UK's legally backed currency, as well as the restricted opportunities for conversion. Despite high levels of competition at the height of the cash-for-gold boom, even then the points of exchange were far more limited than the opportunities to realize the value of British pounds and pence. In addition, in every one of these situations, the value of the jewelry in question could be realized only through being converted into the national fiat currency. So while gold jewelry acts as a store of wealth, it remains less liquid than, and comparable only through, the legally sanctioned fiat currency. The jewelry collection exists as a type of para-money, rather than an independent or even stand-alone monetary system. 
That said, I would contend that as well as being less than 'full' money, gold jewelry is also something more. With regard to the money chain, it was precisely the ambiguity of the object that allowed it to be used as a mediator in especially sensitive situations. For the modern jewelry collection, this is equally the case. It is the lack of any confirmed monetary status of gold jewelry, as well as its recognizable value, that makes it such an appropriate gift at these moments. In situations where offering an acknowledged currency would be considered too uncouth or mercenary, and where appearances or at least reasonable doubt needs to be maintained, gold jewelry remains the most appropriate token of exchange.

\section{Acknowledgments}

The fieldwork that underpins much of this article was made possible due to an Arts and Humanities Research Council (AHRC) Doctoral Training Award. I would like to express my gratitude for this support, as well as the time and information shared by respondents in the field and the commercial organizations that permitted me access to their highly restricted sites and activities.

Peter Oakley is a Senior Research Tutor in the School of Arts and Humanities at the Royal College of Art in London. His research interests include the social identities of prestige materials and luxury goods, the introduction and retention of manufacturing techniques and processes, ethical material sourcing initiatives and certification programs, and the social impact of material standards and related analytical techniques. He is a Fellow of the Royal Anthropological Institute, an Honorary Research Fellow at the University College London, and an Associate Member of the Winchester Luxury Research Group.

\section{Notes}

1. For a review of object categorizations, see Margolis and Laurence (2007).

2. See the discussions about recursive divisibility and the sorites paradox in the introduction to this special issue.

3. See "Hallmarking Act 1973," Her Majesty's Government, National Archives, http:// www.legislation.gov.uk/ukpga/1973/43. 


\section{References}

Bernstein, Peter L. 2004. The Power of Gold: The History of an Obsession. Chichester: John Wiley \& Sons.

Blas, Javier, and James Mackintosh. 2009. "Hedge Fund Offers to Price Shares in Gold.” Financial Times, 29 January. https://www.ft.com/content/efe1a910-ed98 -11dd-bd60-0000779fd2ac.

Bordo, Michael D., and Anna J. Schwartz. 1996. "The Operation of the Specie Standard: Evidence for Core and Peripheral Countries, 1880-1990." In Currency Convertibility: The Gold Standard and Beyond, ed. Jorge Braga de Macedo, Barry Eichengreen, and Jaime Reis, 85-100. London: Routledge.

Bourdieu, Pierre. (1984) 2008. Distinction: A Social Critique of the Judgement of Taste. Trans. Richard Nice. London: Routledge \& Kegan Paul.

Buchan, James. 1997. Frozen Desire: An Inquiry into the Meaning of Money. New York: Farrar, Straus and Giroux.

Bury, Shirley. 1984. An Introduction to Rings. London: Her Majesty's Stationery Office.

Clark, Grahame. 1986. Symbols of Excellence: Precious Materials as Expressions of Status. Cambridge: Cambridge University Press.

Clark, Neil D. L. 2014. Scottish Gold: Fruit of the Nation. Castle Douglas: Neil Wilson.

Clay, Richard, and Sue Tungate, eds. 2009. Matthew Boulton and the Art of Making Money. Studley: Brewin Books.

Cocks, Anna S. 1980. An Introduction to Courtly Jewellery. London: Pitman Publishing. CPM Group. 2014. The CPM Gold Yearbook 2014. London: Euromoney.

Dormer, Peter, and Ralph Turner. 1985. The New Jewelry: Trends and Traditions. London: Thames \& Hudson.

Eichengreen, Barry, and Marc Flandreau, eds. 1985. The Gold Standard in Theory and History. London: Methuen.

Eisen, Sarah, ed. 2012. Currencies After the Crash: The Uncertain Future of the Global Paper-Based Currency System. New York: McGraw-Hill.

English, Simon. 2012. "Good for Barry, but Rise of Pawnbroking's Still a Worry.” Evening Standard, 21 February. http://www.standard.co.uk/business/markets/goodfor-barry-but-rise-of-pawnbrokings-still-a-worry-7445419.html.

Evans, Joan. (1953) 1970. A History of Jewelry: 1100-1870. London: Faber \& Faber.

Event Guides. 2011. The Jewelry Show Official Show Catalogue. Carlisle: Event Guides Ltd.

Flood, Chris. 2010. "Investors Outshone Jewellery Buyers in Gold Rush of 2009." Financial Times, 14 January.

Forsyth, Hazel. 2013. London's Lost Jewels: The Cheapside Hoard. London: I. B. Tauris.

Fuller, Christopher J. 1989 "Misconceiving the Grain Heap: A Critique of the Concept of the Indian Jajmani System." In Money and the Morality of Exchange, ed. Jonathan Parry and Maurice Bloch, 33-63. Cambridge: Cambridge University Press.

Godelier, Maurice. 1971. “'Salt Currency’ and the Circulation of Commodities among the Baruya of New Guinea.” In Studies in Economic Anthropology, ed. George Dalton, 52-73. Washington, DC: American Anthropological Association.

Goffman, Erving. 1951. "Symbols of Class Status.” British Journal of Sociology 2 (4): 294-304.

Goldsmiths. 2011. Goldsmiths Fair '11. London: Goldsmiths Company.

Green, Timothy. 1968. The World of Gold. London: Michael Joseph.

Green, Timothy. 1982. The New World of Gold: The Inside Story of the Mines, the Markets, the Politics, the Investors. London: Weidenfield \& Nicolson. 
Harding, Robin, Javier Blas, and Alan Beattie. 2010. “World Economy: In Gold They Rush.” Financial Times, 12 November. https://www.ft.com/content/d77d01f8-ee90 -11df-9db0-00144feab49a.

Hart, Matthew. 2013. Gold: The Race for the World's Most Seductive Metal. London: Simon \& Schuster.

Holbraad, Martin. 2005. "Expending Multiplicity: Money in Cuban Ifá Cults.” Journal of the Royal Anthropological Institute 11 (2): 231-254.

IOD (Institute of Directors). 2013. "Gerald Ratner Speaking at the 1991 Institute of Directors Annual Convention.” YouTube, 3 May. https://www.youtube.com/ watch? $\mathrm{v}=$ Nj9BZz71yQE.

Kinder, Gary. 1998. Ship of Gold in the Deep Blue Sea. London: Little, Brown.

Klare, Normand E. 1991. The Final Voyage of the Central America, 1857: The Saga of a Gold Rush Steamship, the Tragedy of Her Loss in a Hurricane, and the Treasure Which Is Now Recovered. Glendale: Arthur H. Clark.

Levenson, Thomas. 2009. Newton and the Counterfeiter: The Unknown Detective Career of the World's Greatest Scientist. London: Faber \& Faber.

Lewis, Nathan. 2007. Gold: The Once and Future Money. Hoboken, NJ: John Wiley \& Sons.

Lightbrown, Ronald W. 1992. Medieval European Jewellery. London: Victoria and Albert Publications.

Margolis, Eric, and Stephen Laurence, eds. 2007. Creations of the Mind: Theories of Artifacts and Their Representation. Oxford: Oxford University Press.

Mattingly, Phil, and Robert Schmidt. 2010. “Ron Paul's Moment.” Bloomberg Businessweek, 6-12 December.

McLuhan, Marshall. (1964). 2001. Understanding Media. London: Routledge.

Muller, Priscilla E. 1972. Jewels in Spain: 1500-1800. New York: Hispanic Society of America.

Oakley, Peter. 2013. "Containing Precious Metals: Hallmarking, Minting and the Materiality of Gold and Silver in Medieval and Modern England." In Mobility, Meaning and Transformations of Things: Shifting Contexts of Material Culture through Time, ed. Hans Peter Hahn and Hadas Weiss, 63-77. Oxford: Oxbow Books.

O’Connell, Rhona, Cameron Alexander, Andrew Leyland et al. 2013. Gold Survey 2013 Update 1. London: Thomson Reuters GFMS. http://share.thomsonreuters.com/PR/ Misc/GFMS/GoldSurvey2013Update1.pdf.

Orrling, Carin. 2002. The Gold Room. Stockholm: Statens Historiska Museum.

Porteous, John. 1973. Coins. London: Octopus Books.

Ratner, Gerald. 2007. The Rise and Fall ... and Rise Again. Chichester: Capstone.

Reed Exhibitions. 2011. International Jewellery London 2011 Essential Guide. London: Publishing Events.

Saner, Emine. 2012. "Gold Fever.” G2, 1 February.

Shaughnessy, Carol. 2004. Diving into Glory: The Mel Fisher Maritime Museum. Key

West, FL: Mel Fisher Maritime Heritage Society.

Simmel, Georg. 1997. "Adornment.” In Simmel on Culture: Selected Writings, ed. David Frisby and Mike Featherstone, 206-211. London: Sage.

Weiner, Annette B. 1992. Inalienable Possessions: The Paradox of Keeping-While-Giving. Berkeley: University of California Press.

Yuran, Noam. 2014. What Money Wants: An Economy of Desire. Stanford, CA: Stanford University Press.

Zelizer, Viviana A. 1997. The Social Meaning of Money: Pin Money, Paychecks, Poor Relief, and Other Currencies. Princeton, NJ: Princeton University Press. 